\title{
THE FIXED BED COLUMN SORPTION STUDY FOR THE NITRATE REMOVAL BY A CATIONIC MODIFIED INEDIBLE PUMPKIN SHEEL
}

Dragana Marković Nikolić1, Goran Petković1, Nebojša Ristić1, Danijela Bojić2, Miloš Durmišević ${ }^{3}$, Stanko Žerajić ${ }^{3}$, Goran S. Nikolić ${ }^{*}$

\footnotetext{
${ }^{1}$ Academy of Professional Studies South Serbia, Department of Technology and Art Studies, Leskovac, Serbia

2Department of Chemistry, Faculty of Sciences and Mathematics, University of Niš, Niš, Serbia

3 University of Niš, Faculty of Technology, Leskovac, Serbia
}

A fixed bed column was applied to remove nitrate ions from an aqueous solution using a cationic modified pumpkin shell as a sorbent. The fixed bed column performances were assessed by varying the influent nitrate concentrations $\left(50 \mathrm{mg} \mathrm{dm}^{-3}\right.$ and $\left.100 \mathrm{mg} \mathrm{dm}^{-3}\right)$ and flow rates $\left(20 \mathrm{~cm}^{3} \mathrm{~min}^{-1}\right.$ and $\left.40 \mathrm{~cm}^{3} \mathrm{~min}^{-1}\right)$ with $13 \mathrm{~cm}$ bed height of the sorbent. The obtained results showed that increase of the concentration of the initial nitrate solution affects the increase in the amount of nitrate in the effluent and reduces the breakthrough time. A higher flow rate led to the faster column exhaustion, resulting in the shortened lifespan of the column. In this study, the best nitrate removal was achieved for an initial nitrate solution of $100 \mathrm{mg} \mathrm{dm}^{-3}$ at the flow rate of $20 \mathrm{~cm}^{3} \mathrm{~min}^{-1}$, when a total nitrate removal of $86 \%$ is reached. The relationship between the sorption capacity of this sorbent and the varied parameters was assessed and predicted using two different theoretical breakthrough curve models: the Thomas and Yoon-Nelson models. This study confirmed that the cationic modified pumpkin shell in the fixed bed column has good potential for removing nitrate from aqueous solutions.
(ORIGINAL SCIENTIFIC PAPER)

UDC 66.081:635.62

DOI: $10.5937 /$ savteh2002005M
Keywords: pumpkin shell, nitrate sorption, fixed bed column, breakthrough curve modeling

\section{Introduction}

High concentrations of nitrate in natural waters cause significant environmental problems through eutrophication [1], primarily in drinking water endangering human health (methaemoglobinaemia, cancer) [2]. Numerous methods for the removal of nitrate from water solutions are available, such as a biological treatment [1], electrodialysis [3], reverse osmosis [4], adsorption [5,6], ion exchange [7], and the reduction by zerovalent iron [8]. Recently, growing interest in the utilization of biomass has stimulated the extensive research into cheap lignocellulosic sorbents for the removal of anionic pollutants [9-14], primarily nitrate $[15,16]$. Various lignocellulosic materials (such as sawdust, tree bark, fruit shells, pomace and straw) can be used as such only for cation sorption [17]. In order to enable the binding of anions, chemical modification (i.e. cationization) of the lignocellulosic material is required. For this purpose, several modification methods involving the incorporation of quaternary ammonium groups have been introduced, forming the anion exchange resins from agricultural residues through reactions with epichlorohydrin and dimethylamine or rimethylamine in the presence of pyridine $[11,18]$. Furthermore, N-(3-chloro-2-hydroxypropyl) trimethylammonium chloride has been used to produce an anion exchange sorbent from Lagenaria vulgaris together with $\mathrm{NaOH}$ [12].

Based on the literature search it can be concluded that the fixed bed column studies for removing various contaminants from synthetic wastewater are still in the very infancy
[19]. Compared with other sorption studies (for example in the batch mode), the column study was found to be better, easier, simpler, more economical, and feasible for the industrial use to remove various contaminants. The recent literature provides an overview of the development of various sorbents for the removal of many pollutants (sorbates), such as the removal of metal ions, anions, dyes and other pollutants using the fixed bed column study concerning operation parameters [19].

\section{Continuous fixed bed technique.}

Batch, a continuous moving bed, a continuous fixed bed (upflow or downflow), a continuous fluidized bed and a pulsed bed are various types of the technique by which the contact between sorbate and sorbent mainly occurs in the sorption system. Each method has its advantages and disadvantages [19]. A fixed bed column is more preferable and industrially feasible for the removal of various contaminations from synthetic, as well as real wastewater. The performance of the fixed bed column is studied by breakthrough curves, i.e. the representation of the pollutant-effluent concentration versus time profile in a fixed bed column.

Breakthrough curves and their parameters are interpreted for the design of different columns. Numerous process parameters are known to have an important influence on this phenomenon: the initial sorbate concentration, flow rate, bed height, $\mathrm{pH}$, sorbent particle size and temperature. In addi-

\footnotetext{
*Author address: Goran S. Nikolić, University of Niš, Faculty of Technology,

Bulevar oslobođenja 124, Leskovac 16000, Serbia

E-mail: gnikolic@tf.ni.ac.rs; goranchem_yu@yahoo.com

The manuscript received: September, 09, 2020.

Paper accepted: November, 09, 2020.
} 
tion, it should be borne in mind that the ion concentration of the wastewater and co-existing ions affect the lifetime of the biosorbent material and the sorption efficiency. Therefore, it is important to know the effects of these and other factors when the sorbent is applied on an industrial scale, especially on a fixed bed column [19].

The relation between the nature of breakthrough curves and fixed bed sorption was as adequately expressed using the mass transfer zone (MTZ) or the primary sorption zone (PSZ). As shown in Figure 1, feed water (wastewater) is inserted through the inlet of the column, the sorbate is sorbed most rapidly and effectively by the upper few layers of the fresh sorbent during the initial stage of the operations [19]. This is due to the higher amount of the sorbent and small levels of the sorbate available at these upper layers, so that the sorbate is readily escaped in the lower strata of the bed and no sorbate (pollutants) run off from the sorbent at the first stage. So, a primary sorption zone or MTZ is attained near the top or influent end of the column. At this point, the concentration of the sorbate $(C)$ is zero, and thus, the ratio of the effluent and the initial concentration $\left(C / C_{0}\right)$ is zero. Thereafter, the upper layer of the sorbent is gradually saturated, with feeding the polluted water (sorbate) into the column, which becomes sorbent less efficient progressively. Thus, the primary sorption zone also travels descending to fresher or unadsorbed part of the sorbent in the column. Further, with the movement of this zone, the tendency is that more and more sorbate come out in the effluent as per points $C_{1} / C_{0}, C_{2} / C_{0}$, $\mathrm{C}_{3} / \mathrm{C}_{0}$ and $\mathrm{C}_{4} / \mathrm{C}_{0}$. The movement of this zone is mainly increasing with increasing the initial concentration compared to linear velocity of the feed water. After some time $(C s)$, the column is completely saturated or exhausted and thereafter sorption does not occur. At this point, the ratio of $C / C_{0}$ is 1 . In most cases of the water and wastewater treatment by sorption on the column, the breakthrough curves show a characteristic "S" shape, but with different degrees of the slope [20].

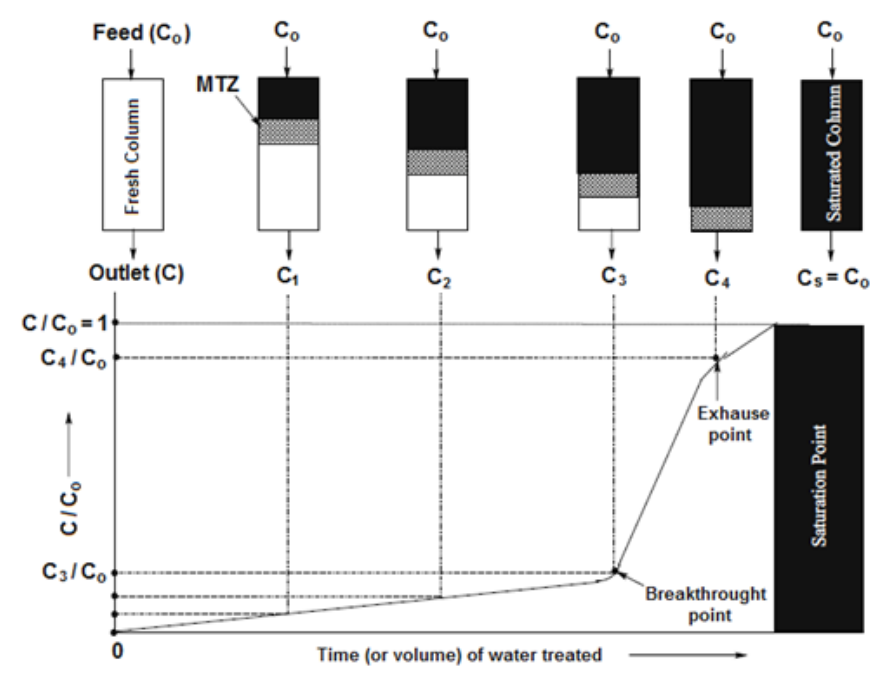

Figure 1. Presentation of a breakthrough curve by movement of MTZ [19]

As shown in Figure 1, initially the sorbent is regarded to be exhausted easily; a breakthrough point is selected arbitrarily at the lower value of the break point concentration $\left(C_{b}\right)$ for the effluent concentration and exhaustion point concentration $\left(C_{e}\right)$ closely imminent influent concentration of the sorbate [19]. The primary sorption zone (PSZ) is the portion between the exhaustion point $\left(C_{e}\right)$ and the breakthrough point concentration of the sorbate $\left(C_{b}\right)$. If PSZ is assumed to have a constant length or depth $(\delta)$, some important parameters such as total time taken for the primary sorption zone to establish itself $(t e)$, time required for the exchange zone to move the length of its own height up/down the column $(t \overline{)})$, rate at which the exchange zone is moving up or down through the bed $\left(U_{z}\right)$, fraction of the sorbate present in the sorption zone and the percentage of the total column saturated at breakthrough are calculated using simple equations. These parameters play a vital role column designing [21].

\section{Sorption models for the column study.}

The mechanism of this sorption is based on different phenomena, like axial dispersion, film diffusion resistance, intraparticle diffusion resistance (both pore and surface diffusion) and sorption equilibrium with the sorbent [22]. A detailed description of the column isotherm models is given to understand the sorption system. Various practical features such as sorbent capacity, operating life span, regeneration time and the prediction of the time necessary play a vital role during the operation of the column using sorption dynamics acquaintance and modeling. Also, these models provide detailed conclusions about the mechanism of the process [19]. The sorption column is subjected to axial dispersion, external film resistance and intraparticle diffusion resistance. So, the mathematical correlations for the sorption in fixed bed columns assume of axial dispersion, external mass transfer, intraparticle diffusion and nonlinear isotherms.

Several mathematical models have been developed for the evaluation of the efficiency and applicability of the column models for large-scale operations. Thomas, Yoon-Nelson, bed-depth service time, the Adams and Bohart model, Clark, Wolborska and the modified doseresponse model are the most commonly used to analyze the column behavior of the sorbent-sorbate system. The most general and widely used for column studies is the Thomas model [23]. The maximum solid-phase concentration of sorbate on sorbent and rate constant is determined using the data obtained from column continuous studies by the Thomas sorption model. The Thomas model is proposed on the assumption of Langmuir kinetics of sorption-desorption that rate driving forces follow second-order reversible reaction kinetics and no axial dispersion. The Yoon-Nelson model [24] is a simple theoretical assumption which does not concentrate upon properties of sorbate, a type of sorbent and any physical features of the sorption bed. This model is given a probable statement that a decrease in the rate of the sorption is directly proportional to the sorbate sorption and breakthrough on the sorbent. 
The adsorption capacity of each model for different process parameters such as the initial concentration of the sorbate, bed height, flow rate, etc. is calculated and mentioned by various scientists for designing the column [19]. It also mentioned the variation, i.e., the increase or a decrease in the column sorption model parameters with respect to increasing the operation parameters. Very important parameters of the Thomas model, the sorption capacity of ions uptake $\left(q_{T H}\right.$ increased with the increase in the initial concentration of the sorbent, bed height and temperature, and corresponding the Thomas rate constant $\left(k_{T H}\right)$, values decreased. Also, $q_{T H}$ decreased with the increase in the flow rate, and corresponding $k_{T H}$ ) values increased. Further, the correlation coefficient value $\left(R^{2}\right)$ from a straight line graph of all models is calculated and mentioned in most of the research papers. The coefficient of determination is useful because it gives the proportion of the variance (fluctuation) of one variable that is predictable from other variables. It is a measure that allows us to determine how certain one can be in making predictions from a certain model. This value plays an important role for any sorption isotherm. If a coefficient value is closer to unity, then it indicates the most suitable isotherm model [25].

The aim of the study.

In our previous studies [26], the sorption of nitrate onto cationic modified Lagenaria vulgaris shell (LVS) in batch mode was found to be very rapid (30-60 min), efficient $\left(15.76 \mathrm{mg} \mathrm{g}^{-1}, \mathrm{R} 2>0,99\right)$ and reversible, and the sorption efficiency was maintained in the $\mathrm{pH}$ range 6-7. This sorbent was synthesized by reacting LVS with epichlorohydrin and trimethylamine in the presence of N,Ndimethylformamide and pyridine as a catalyst. However, the fixed bed column sorption of nitrate for this sorbent has not been investigated yet. The aim of this study is to explain the effects of the initial nitrate concentration, as well as the effect of flow rates on the removal of nitrate from synthetic solutions.

\section{Experiment}

Reagents.

All chemicals used in the experiments were of analytical grade. The stock solution of nitrate $\left(1000 \mathrm{mg} \mathrm{dm}^{-3}\right)$ was prepared by dissolving sodium nitrate $\left(\mathrm{NaNO}_{3}\right.$, Merck) in ultrapure Milli-Q water (Merck Millipore). Solutions used in the sorption tests were diluted from the stock solutions.

Materials and sorbent preparation.

Pumpkin shell (Lagenaria vulgaris) was used as the initial lignocellulosic material in this experiment. The naturally dried pumpkin shell was crushed into small pieces (1-2 cm), milled in a crusher mill (Waring 8010 ES, Germany) and sieved (Oct-Digital 4527) to separate the sizes between 400 and $800 \mu \mathrm{m}$. Chemical modification of the pumpkin shell was carried out according to the literature procedure for the quaternary ammonium modified sorbent preparation [11]. The dried and milled shell $(10 \mathrm{~g})$ was suspended in DMF $\left(60 \mathrm{~cm}^{3}\right)$ at room temperature. After the adjustment of $\mathrm{pH}$ value at 10 , using the $5 \mathrm{M} \mathrm{NaOH}$ solution, the mixture was stirred for $30 \mathrm{~min}$ at $80^{\circ} \mathrm{C}$ in a three-neck round bottom flask (250 $\left.\mathrm{cm}^{3}\right)$. Afterwards, in the flask epichlorohydrin $\left(50 \mathrm{~cm}^{3}\right)$ was added and the reaction was carried out at $80^{\circ} \mathrm{C}$ for $2 \mathrm{~h}$. The reaction product was washed with an aqua diluted ethanol (1:1) at $40^{\circ} \mathrm{C}$. Quaternary ammonium groups were then introduced into the epoxypropyl by-product after the reaction with trimethylamine $\left(50 \mathrm{~cm}^{3}\right)$ in the presence of pyridine $\left(20 \mathrm{~cm}^{3}\right)$ as a catalyst. This synthesis was performed in the three-necked flask at $80^{\circ} \mathrm{C}$ for $4 \mathrm{~h}$. The product was washed with the ethanol solution $(50 \%)$ followed by $\mathrm{NaOH}(0.1 \mathrm{M})$ and $\mathrm{HCl}(0.1 \mathrm{M})$ to remove the residual chemicals. Finally, the cationic product was washed with deionized water at $40^{\circ} \mathrm{C}$ and vacuum dried at $40{ }^{\circ} \mathrm{C}$ for $2 \mathrm{~h}$. The resulting sorbent was then used in all sorption experiments.

Characterization methods.

The constituents, physical properties, elemental analysis (CHNS/O), FTIR characterization, SEM-EDX analysis and morphology of raw and modified pumpkin shell (sorbent) were determined according to the standard AOAC and AACC procedures and described in the previous study $[10,11]$.

\section{Fixed-bed column preparation.}

Continuous flow sorption studies were conducted in a column made of the Pyrex glass tube having the inner diameter of $3 \mathrm{~cm}$ and $15 \mathrm{~cm}$ length. A sieve made up of stainless steel was placed at the bottom of the column. Over the sieve, a layer of glass wool was placed to prevent the loss of sorbent during the nitrate sorption process. A peristaltic pump was used to pump the feed downward through the column at a desired flow rate. A certain amount of the prepared sorbent $(20 \mathrm{~g})$ was loaded into the column to obtain a bed depth of $13 \mathrm{~cm}$. Prior to the start of sorption, the sorbent packed in the column was wetted with deionized water (downstream) to remove the trapped air between the sorbent particles (size $0.4-0.8 \mathrm{~mm}$ ).

\section{Continuous sorption process.}

The experiment was conducted at ambient temperature $\left(23 \pm 1{ }^{\circ} \mathrm{C}\right)$. The nitrate solution (influent) was continuously fed (downstream) to the column by a peristaltic pump. The initial $\mathrm{pH}$ value of the influent solution was 6.5. The fixed bed column performances and effects of the nitrate solution concentration ( 50 and $100 \mathrm{mg} \mathrm{dm}^{-3}$ ) and flow rates (20 and $40 \mathrm{~cm}^{3} \mathrm{~min}^{-1}$ ) with $13 \mathrm{~cm}$ bed depth of the sorbent were examined. The volume of the sorbent bed was $91 \mathrm{~cm}^{3}$. Test samples were collected every 10 minutes from the bottom of the column and the absorbance was measured at $220 \mathrm{~nm}$ for the remaining nitrate content using a UV-VIS spectrophotometer (Cary- 
100 Conc., Varian), by the standard $4500-\mathrm{NO}_{3}$ method [27]. The column performance was investigated by calculating the breakthrough time and sorption capacity.

\section{Mathematical studies.}

The breakdown curve of a continuous fixed bed column can be used to estimate the efficiency of the sorption process [28]. The breakthrough curve is described as $C_{t} / C_{0}$ against the contact time $(t)$, where $C_{0}(\mathrm{mg}$ $\left.\mathrm{dm}^{-3}\right)$ represents the inlet concentration and $C_{t}(\mathrm{mg} \mathrm{dm}$ ${ }^{3}$ ) the outlet concentration of the nitrate solution at time $t$ (min). To estimate the breakthrough curve, the breakthrough time $\left(t_{b}, \mathrm{~min}\right)$ and the exhaustion time (te, min) were determined when the effluent nitrate concentration $\left(C, \mathrm{mg} \mathrm{dm}^{-3}\right)$ reached $10 \%$ and $90 \%$ of the initial nitrate concentration $\left(\mathrm{C}_{0}, \mathrm{mg} \mathrm{dm}^{-3}\right)$, and defined as $C_{t} / \mathrm{C}_{0}=0.1$ and 0.9 , respectively (Figure 2 ). The sorbed ion concentrations $\left(C_{s}\right)$ in the column:

Cs $\left(\mathrm{mg} \mathrm{dm}^{-3}\right)=$ inlet concentration $\left(C_{0}\right)$ - outlet concentration $(C t)$...

were confirmed by a plot of the sorbed concentration or the normalized concentration assigned as the ratio of the effluent concentration to the influent concentration $\left(C_{t} /\right.$ $C_{0}$ ) as a function of time or the volume of the effluent ( $V$ eff), as presented in equation (2). The $Q$ and ttotal describe the volumetric flow rate $\left(\mathrm{cm}^{3} \mathrm{~min}^{-1}\right)$ and total flow time ( $\min )$, respectively.

$V_{\text {eff }}\left(\mathrm{cm}^{3}\right)=\mathrm{Q} \cdot$ total

The total sorbed ion ( $q_{\text {total }}$ ) by the column can be calculated by equation (3), i.e. by integrating the plot of the sorbed concentration $(C s)$ versus the flow time $(t)$, where $t_{\text {total }}$ is the total time for the column to reach saturation (min), $Q$ is the volumetric flow rate $\left(\mathrm{cm}^{3} \mathrm{~min}^{-1}\right), C s$ is the concentration of sorbed nitrate $\left(\mathrm{mg} \mathrm{dm}^{-3}\right)$.

$$
q_{\text {total }}(\mathrm{mg})=\frac{Q}{1000} \int_{t=0}^{t=t_{\text {total }}} C_{S} d t
$$

The total amount of ions delivered to the column system $\left(m_{\text {total }}\right)$ is gained from equation (4).

$m_{\text {total }}(\mathrm{mg})=\frac{C_{0} Q t_{\text {total }}}{1000}$

The column performance can be examined by the total removal percentage ( $\left.R_{\text {total }}\right)$ of ions from the ratio of total sorbed ions in the column to the total amount of ions delivered to the column, as shown in equation (5).

$R_{\text {total }}(\%)=100 \cdot \frac{Q_{\text {total }}}{m_{\text {total }}}$

The equilibrium sorption was also calculated from the column data to obtain the capacity of the sorbent required for ions removal. Equation (6) declares the equilibrium ion uptake ( $q$ eq), also known as the column maximum capacity, where $m$ is the unit mass of the sorb- ent packed in the column.

$q_{\text {eq }}\left(\mathrm{mg} \mathrm{g}^{-1}\right)=\frac{Q_{\text {total }}}{m}$

Moreover, the cumulative nitrate retention curve represents the total mass of nitrate sorbed on the sorbent ( $\mathrm{mg} \mathrm{N} / \mathrm{g}$ sorbent) as a function of empty bed volumes of flow that pass through the column. In this regard, the following equation (7) can be used to calculate the cumulative nitrate retention $(q i)$ by the column:

$q_{i}=\frac{Q \sum_{i=1}^{n}\left(C_{0}-C_{i}\right) \Delta t_{i}}{m}$

where $q_{i}\left(\mathrm{mg} \mathrm{g}^{-1}\right)$ is the cumulative nitrate retention by the sorbent at time ti $(\mathrm{min}), Q\left(\mathrm{~cm}^{3} \mathrm{~min}^{-1}\right)$ is the flow rate, $C_{0}\left(\mathrm{mg} \mathrm{dm}^{-1}\right)$ is the influent nitrate concentration, $C_{i}(\mathrm{mg}$ $\mathrm{dm}^{-3}$ ) is the average effluent nitrate concentration between time $t_{i}$ and $t_{i-1}, \Delta t_{i}$ is time difference $\left(t_{i}-t_{i-1}\right)$ (min), and $m$ is the material mass $(\mathrm{g})$.

The mass transfer zone (MTZ) is defined as the effective length of the column $(\mathrm{cm})$ where the sorption occurs, and is expressed as follows:

$\mathrm{MTZ}=\mathrm{H} \frac{t_{e}-t_{b}}{t_{e}}$

where $\mathrm{H}$ is the bed height $(\mathrm{cm}), t_{e}$ is the exhaustion time ( $\min )$, and $t_{b}$ is the breakthrough time (min).

\section{Results and discussion}

Continuous sorption study.

The performance of a fixed bed column can be described through the concept of the breakthrough curve analysis [29]. The time to reach the breakthrough point and shape of the breakthrough curve are very important characteristics for determining the operation and the dynamic responses of a sorption column. The nitrate removal process was evaluated using a fixed bed column packed with a cationic modified pumpkin shell as a sorbent. The effect of the sorbate concentration on the column performance was studied by varying the inlet nitrate concentration of 50 and $100 \mathrm{mg} \mathrm{dm}^{-3}$ and feed flow rates of 20 and $40 \mathrm{~cm}^{3} \mathrm{~min}^{-1}$ while the same sorbent bed height of $13 \mathrm{~cm}$ was used. Two values of the initial nitrate concentration (50 and $100 \mathrm{mg} \mathrm{dm}^{-3}$ ) were chosen, because it was determined that the concentrations in this range are typical for wastewater. In this regard, the recommendation of the World Health Organization for the upper limit of the nitrate concentration in drinking water is $50 \mathrm{mg} \mathrm{dm}^{-3}$ [30]. The column experiments were studied at ambient temperature $\left(23 \pm 1^{\circ} \mathrm{C}\right)$, as close as possible to real conditions. Our previous batch sorption study and present optimization [15]both show that the percentage removal of nitrate ions is maximum (31.5\%) at $\mathrm{pH} 6.5$ (sorption capacity of $15.76 \mathrm{mg} \mathrm{g}^{-1}, R^{2} 0,991$ ). Thus, the effect of the flow rate and the influent concen- 
tration was conducted at the nitrate solution $\mathrm{pH}$ of 6.5 . The corresponding breakthrough curves are illustrated below.

\section{Effect of the influent nitrate concentration on breakthrough} curves.

The breakthrough curve $C_{t} / C_{0}$ versus breakthrough time treated with two initial nitrate concentrations (50 and $\left.100 \mathrm{mg} \mathrm{dm}^{-3}\right)$ at the constant flow rate $\left(20\right.$ or $\left.40 \mathrm{~cm}^{3} \mathrm{~min}^{-1}\right)$ is shown in Figure 2. As presumed, the breakthrough of nitrate is strongly dependent on the influent nitrate concentration. From the plot (Figure 2A) it can be deduced that at the lower inlet concentration $\left(50 \mathrm{mg} \mathrm{dm}^{-3}\right)$, a slower breakthrough curve and the highest treated volume are obtained. The breakthrough point for $100 \mathrm{mg} \mathrm{dm}^{-3}$ and $50 \mathrm{mg} \mathrm{dm}^{-3}$ of nitrate inlet concentrations occurred after 36 and $48 \mathrm{~min}$, respectively, at the constant flow rate $\left(20 \mathrm{~cm}^{3} \mathrm{~min}^{-1}\right)$. The slow transport of nitrate ions onto the pumpkin shell was due to the lower concentration gradient and resulted in a slower breakthrough curve. Conversely, a higher concentration of nitrate ions $(100 \mathrm{mg}$ $\mathrm{dm}^{-3}$ ) was shown to lead to a higher driving force for nitrate ions to overcome the mass transfer resistance in the liquid phase. Consequently, quick saturation of the available binding sites for nitrate ions caused the breakthrough time to decrease with the increasing inlet nitrate ions concentration. A similar behavior is observed at the constant flow rate of $40 \mathrm{~cm}^{3} \mathrm{~min}^{-1}$. As it can be seen from the plot (Figure 4B), both the breakthrough time $\left(t_{b}\right)$ and the exhaustion time $\left(t_{e}\right)$ were found to decrease with increasing the inlet concentration. The plot represents that the shape and gradient of the breakthrough curves were slightly different from the variation of the inlet concentration which is also expected.

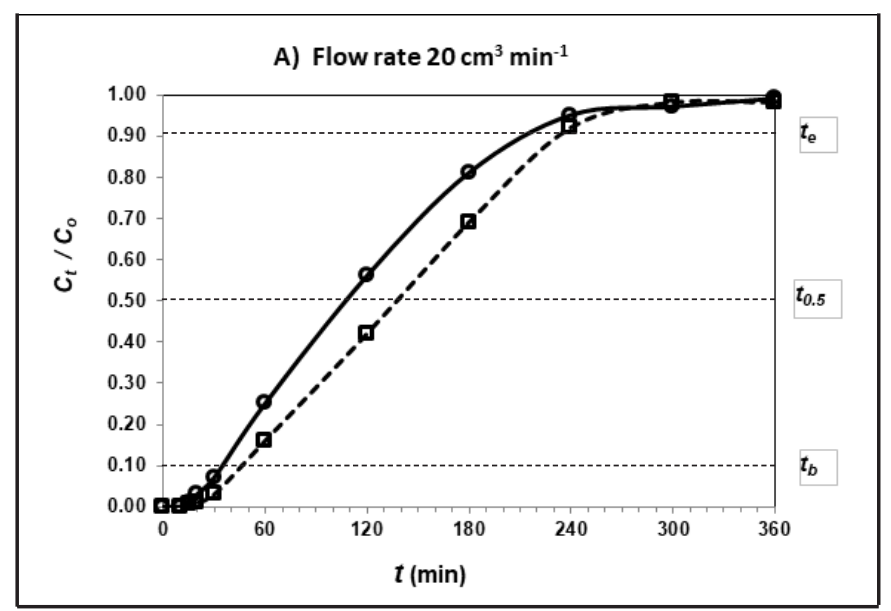

Figure 2. Breakthrough curves for the sorption of nitrate ions onto the pumpkin shell sorbent for different initial concentrations at the flow rate of $20 \mathrm{~cm}^{3} \mathrm{~min}^{-1}(\mathrm{~A})$ and $40 \mathrm{~cm}^{3} \mathrm{~min}^{-1}(B)$.

The increase in qeq of the pumpkin shell from 30.96 to $63,93 \mathrm{mg} \mathrm{g}^{-1}$ for the influent concentration of $100 \mathrm{mg}$ $\mathrm{dm}^{-3}$ and from 15.33 to $31.55 \mathrm{mg} \mathrm{g}^{-1}$ for the influent concentration of $50 \mathrm{mg} \mathrm{dm}^{-3}$ is observed as the flow rate in- creases from 20 to $40 \mathrm{~cm}^{3} \mathrm{~min}^{-1}$ (Table 1). Based on the discussion on the effect of the flow rate, it is suggested that a higher flow rate would be favor to the nitrate sorption in the column tests.

Total removal and sorption capacities.

The detailed experimental results, including breakthrough times $\left(t_{b}\right)$, exhaustion times $\left(t_{e}\right)$, a total amount of nitrate sorbed by the modified pumpkin shell as a sorbent ( $\left.q_{\text {total }}\right)$, the dynamic sorption capacity $\left(q_{\mathrm{eq}}\right)$, and MTZ are presented in Table 1. The obtained results depict that when the flow rate and the concentration were increased, the breakthrough time and the exhaustion time decreased. Accordingly, the values of $q_{\text {total }}$ and $q_{\text {eq }}$ gradually increased. The values of MTZ are very close when the concentration increases for the same flow rate, while the increase in the flow rate leads to a partial increase in MTZ.

Table 1. The fixed bed column performance for nitrate sorption onto the pumpkin shell sorbent (bed depth of $13 \mathrm{~cm}$ ) at various flow rates and concentrations of the influent

\begin{tabular}{|c|c|c|c|c|c|c|c|c|c|}
\hline $\begin{array}{c}Q \\
\left(\mathrm{~cm}^{3} \mathrm{~min}^{-1}\right)\end{array}$ & $\begin{array}{c}C_{0} \\
\left(\mathrm{mg} \mathrm{dm}^{-3}\right)\end{array}$ & $\begin{array}{c}t_{b} \\
(\mathrm{~min})\end{array}$ & $\begin{array}{c}t_{e} \\
(\mathrm{~min})\end{array}$ & $\begin{array}{c}V_{\text {eff }} \\
\left(\mathrm{cm}^{3}\right)\end{array}$ & $\begin{array}{l}m_{\text {total }} \\
(\mathrm{mg})\end{array}$ & $\begin{array}{l}q_{\text {total }} \\
(\mathrm{mg})\end{array}$ & $\begin{array}{l}R_{\text {total }} \\
(\%)\end{array}$ & $\begin{array}{c}q_{\mathrm{eq}} \\
\left(\mathrm{mg} \mathrm{g}^{-1}\right)\end{array}$ & $\begin{array}{l}\text { MTZ } \\
(\mathrm{cm})\end{array}$ \\
\hline & 50 & 48 & 232 & & 360 & 306.65 & 85.18 & 15.33 & 10.31 \\
\hline & 100 & 36 & 212 & & 720 & 619.30 & 86.01 & 30.97 & 10.79 \\
\hline & 50 & 28 & 180 & & 720 & 631.01 & 87.64 & 31.55 & 10.98 \\
\hline & 100 & 22 & 154 & & 1440 & 1278.60 & 88.79 & 63.93 & 11.14 \\
\hline
\end{tabular}

Modeling and the analysis of the column data.

The experimental data obtained from the fixed bed column sorption were analyzed to evaluate the kinetic effect on the concentration-time profile and predict the uptake capacity of the packed sorbent. For this purpose, experimental data were applied in two widely used models: Thomas and Yoon-Nelson model. All the model parameters were evaluated by linear regression using Matlab software.

Application of the Thomas model.

Thomas developed a model for sorption processes in which external and internal diffusion limitations are not present [23]. The Thomas model assumes that the sorption followed the Langmuir isotherm of sorption-desorption, and axial dispersion does not occur in the column. The mathematical equation of the Thomas model was derived with the assumption that the driving force of the sorption follows the second-order kinetics of the reversible reaction. The Thomas equation can be written in its linear form as follows:

$\ln \left[\frac{C_{0}}{C_{t}}-1\right]=\frac{k_{T h} q_{T h} m}{Q}-k_{T h} C_{0} t$

where $k_{T h}$ is the Thomas rate constant $\left(\mathrm{cm}^{3} \mathrm{~min}^{-1} \mathrm{mg}^{-1}\right)$, $q_{T h}$ is the sorption capacity of the nitrate ions uptake $(\mathrm{mg}$ $\left.\mathrm{g}^{-1}\right), C_{0}$ is the inlet nitrate ions concentration $\left(\mathrm{mg} \mathrm{dm}^{-3}\right)$, $\mathrm{C}_{t}$ is the effluent nitrate ions concentration at time $t(\mathrm{mg}$ 
$\left.\mathrm{dm}^{-3}\right), m$ is the mass of the sorbent $(\mathrm{g}), Q$ is the inlet flow rate $\left(\mathrm{cm}^{3} \mathrm{~min}^{-1}\right)$, and $\mathrm{t}$ is the flow time $(\mathrm{min})$. The value of $C_{0} / C t$ is the ratio of inlet to outlet nitrate ions concentrations. A linear plot of $\ln \left[\left(C_{0} / C_{t}\right)-1\right]$ against time $t$ was drawn to determine the values of $q T h$ and $k_{T h}$ from the interception point and the slope of the plot, respectively.

The Thomas model was applied to the data obtained from the removal of nitrate by the fixed bed column at different influent concentrations (50 and $100 \mathrm{mg} \mathrm{dm}^{-3}$ ) and the flow rate $\left(20\right.$ and $40 \mathrm{~cm}^{3} \mathrm{~min}^{-1}$ ), while the column bed height was $13 \mathrm{~cm}$. The linear plots of the Thomas model are presented in Figure 4. The regression analysis suggested that the regression line provides the better fit to the experimental data when the flow rate is $20 \mathrm{~cm}^{3} \mathrm{~min}^{-1}$
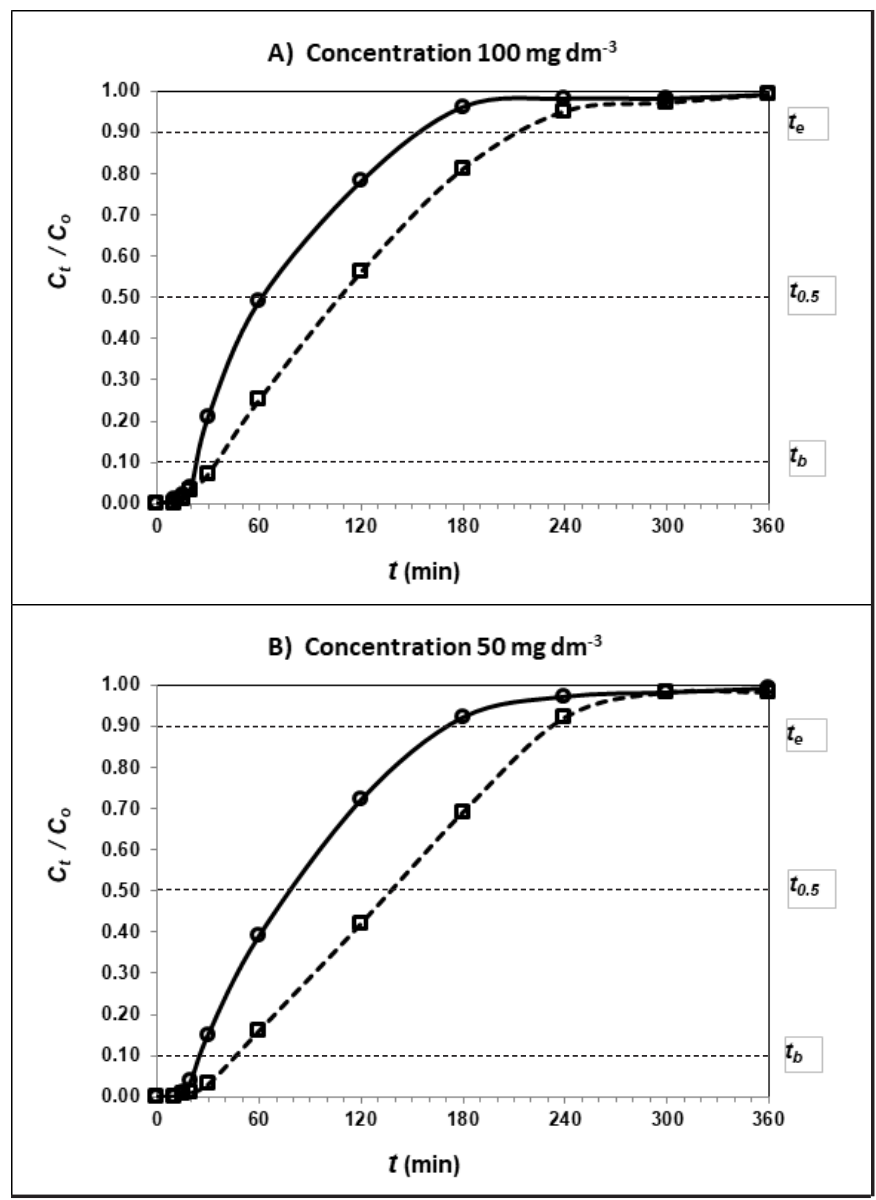

Figure 4. The plot of linear regressions on Thomas model for nitrate sorption on the modified pumpkin shell sorbent at initial concentrations of 50 and $100 \mathrm{mg} \mathrm{dm}^{-3}$ for flow rates of $20 \mathrm{~cm}^{3}$ $\min ^{-1}(\mathrm{~A})$ and $40 \mathrm{~cm}^{3} \mathrm{~min}^{-1}(\mathrm{~B})$

The main statistical parameter, the Thomas rate constant $\left(k_{T h}\right)$ and the sorption capacity $\left(q_{T h}\right)$ were determined from the intercept and the slope of the linear plot, and the corresponding numerical data are presented in Table 2. It is evident that the Thomas model rate constant $\left(k_{T h}\right)$ decreases with increasing the inlet nitrate concentration and flow rate values, while the predicted uptake capacity $\left(q_{T h}\right)$ showed an increasing trend with the increase in both influent nitrate concentrations and the flow rate. The obtained results suggest that the primary driving force for the sorption process is the concentration gradient of the influent [32], i.e. the concentration difference between nitrate ions on the sorbent and nitrate ions in the solution. Thus, due to a higher concentration, the high driving force resulted in a better column performance. The resulting $R^{2}(0.935-0.939)$ provided a better fitting at the lower flow rate $\left(20 \mathrm{~cm}^{3} \mathrm{~min}^{-1}\right)$, suggesting that the Thomas model at lower flow rates can provide a relatively good prediction for the sorption behavior of the pumpkin shell in a fixed-bed column. However, the experimental results are not close to those predicted by the Thomas model. So the correlation between experimental and predicted values using the Thomas model deviated significantly.

The mass transfer is also a phenomenon often present in the sorption process which influences the sorption process, but the Thomas model is only based on the reversible reaction kinetics. Therefore, the design of the sorption system based on the data obtained from only the Thomas model may add the error on modeling. Hence, Yoon-Nelson model was also applied to analyze the breakthrough performance of the fixed bed column.

Table 2. Parameters of Thomas and Yoon-Nelson models for the sorption of nitrate at different flow rates and inlet nitrate concentrations

\begin{tabular}{|c|c|c|c|c|c|c|c|c|}
\hline \multirow{2}{*}{$\begin{array}{c}Q \\
\left(\mathrm{~cm}^{3}\right. \\
\left.\mathrm{min}^{-1}\right)\end{array}$} & \multirow{2}{*}{$\begin{array}{c}\mathrm{C}_{0} \\
(\mathrm{mg} \\
\left.\mathrm{dm}^{-3}\right)\end{array}$} & \multicolumn{3}{|c|}{ Thomas model } & \multicolumn{4}{|c|}{ Yoon-Nelson model } \\
\hline & & $\begin{array}{c}k \\
\left(\mathrm{~cm}^{3} \mathrm{~min}^{-1} \mathrm{mg}^{-1}\right)\end{array}$ & $\begin{array}{c}q_{T h} \\
\left(\mathrm{mg} \mathrm{g}^{-1}\right)\end{array}$ & $R^{2}$ & $\begin{array}{c}k_{Y N} \\
\left(\mathrm{dm}^{3} \mathrm{~min}^{-1}\right)\end{array}$ & $\begin{array}{c}\tau \\
(\min )\end{array}$ & $\begin{array}{c}q_{Y N} \\
\left(\mathrm{mg} \mathrm{g}^{-1}\right)\end{array}$ & $R^{2}$ \\
\hline & 50 & 0.52 & 8.36 & 0.935 & 0.026 & 167.2 & 8.36 & 0.935 \\
\hline & 100 & 0.24 & 14.53 & 0.939 & 0.024 & 145.3 & 14.53 & 0.939 \\
\hline & 50 & 0.46 & 12.69 & 0.886 & 0.023 & 126.9 & 12.69 & 0.886 \\
\hline & 100 & 0.24 & 24.56 & 0.854 & 0.024 & 122.8 & 24.56 & 0.854 \\
\hline
\end{tabular}

Application of Yoon-Nelson model.

The Yoon-Nelson model assumes that the rate of decrease of the sorption probability for each sorbate molecule is proportional to the probability of the sorbate sorption and sorbate breakthrough on the sorbent [24] The linear form of Yoon-Nelson equation can be written as follows:

$\ln \left[\frac{C_{t}}{C_{0}-C_{t}}\right]=k_{Y N} t-\tau k_{Y N}$

where $k_{Y N}$ represents the rate constant of Yoon-Nelson model and $\mathrm{T}$ is the time at which $50 \%$ of sorbate sorbed. A linear plot of $\ln \left[\left(\mathrm{C}_{t} /\left(\mathrm{C}_{0}-\mathrm{C}_{\mathrm{t}}\right)\right]\right.$ against time $\mathrm{t}$ was drawn to determine the values of $k_{Y N}$ and $\mathrm{t}$ from the slope and the interception point of the plot, respectively. In general, due to the symmetric nature of the breakthrough curve, the fixed bed should sorb half of the nitrate passed through the column within $t=2 \tau$. Hence, the following equation can be derived for the uptake capacity of the fixed bed column:

$q_{Y N}=\frac{q_{\text {total }}}{m}=\frac{\left(\frac{1}{2}\right) C_{0}\left(\frac{Q}{1000}\right) 2 \tau}{m}=\frac{C_{0}-Q_{\tau}}{1000 m}$ 
Thus, the uptake capacity $\left(q_{Y N}\right)$ can be determined as a function of various parameters such as the influent concentration $\left(C_{0}\right)$, flow rate $(Q)$, sorbent mass $(m)$, and time ( $\mathrm{T}$ ) corresponding to the $50 \%$ breakthrough using Yoon-Nelson model. The nitrate sorption data obtained from the fixed bed column experiments was explored by using the mathematical equation (10) of the Yoon-Nelson model. Figure 5 shows linear plots of the model at two influent concentrations (50 and $100 \mathrm{mg} \mathrm{dm}^{-3}$ ) and two flow rates (20 and $40 \mathrm{~cm}^{3} \mathrm{~min}^{-1}$ ).

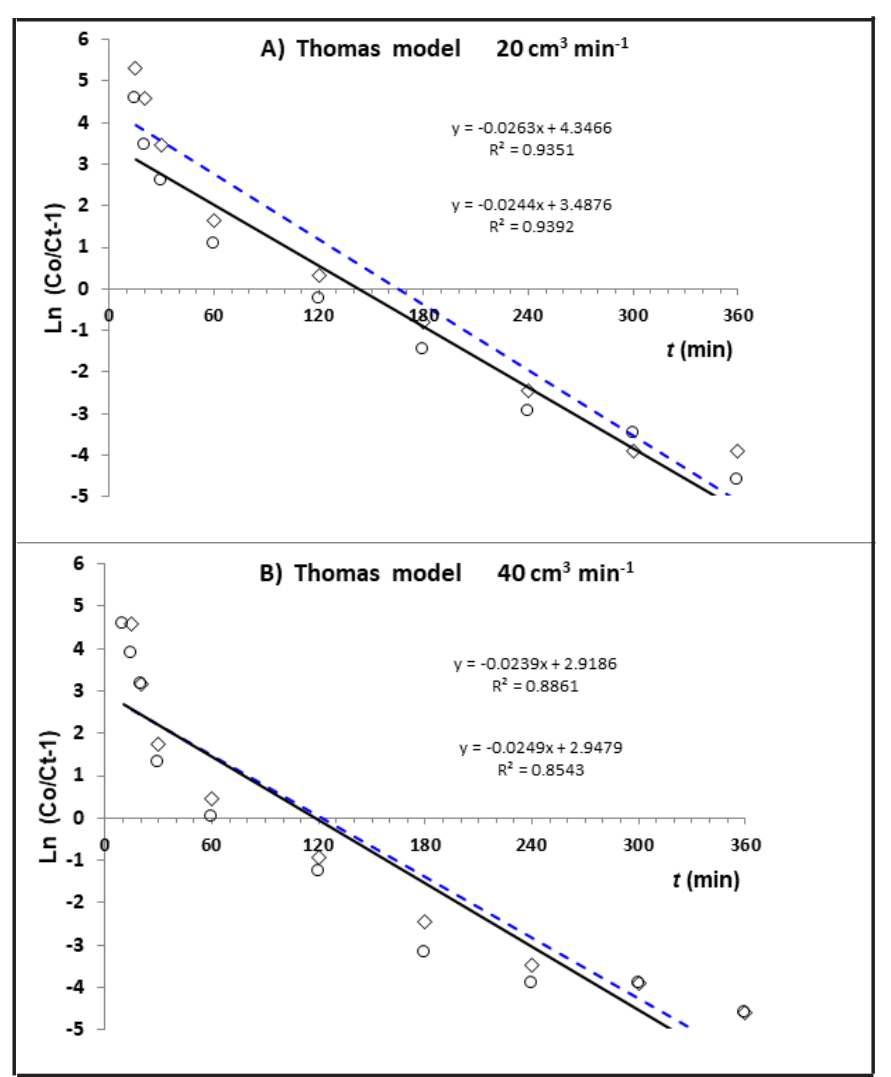

Figure 5. The plot of linear regressions on Yoon-Nelson model for nitrate sorption on the modified pumpkin shell sorbent at initial concentrations of 50 and $100 \mathrm{mg} \mathrm{dm}^{-3}$ for flow rates of 20 $\mathrm{cm}^{3} \min ^{-1}(\mathrm{~A})$ and $40 \mathrm{~cm}^{3} \mathrm{~min}^{-1}(\mathrm{~B})$

The regression analysis of linear plots for the flow rate of $20 \mathrm{~cm}^{3} \mathrm{~min}^{-1}$ (Figure 5A) proved the applicability of the Yoon-Nelson model for the sorption of nitrate due to significant values of correlation coefficients. Table 2 shows the values of the rate constant, the uptake capacity, $\mathrm{T}$ , as well as a statistical parameter at different conditions. Thus, the values of $k_{Y N}$ (Yoon-Nelson rate constant) and T (time corresponding to the 50\% breakthrough) could be obtained from the linear regression analysis. The values of $k_{Y N}$ are slightly changed with increasing the initial nitrate concentration and the flow rate.

The values of $k_{Y N}$ at higher initial concentrations are related to elevate the driving force caused by a higher concentration gradient, which controls the mass transfer in the liquid phase. Similar to the Thomas model, the sorption capacity of the nitrate ions uptake $\left(q_{Y N}\right)$ in- creased with increasing the initial phosphate concentration and the flow rate, following the same trend as that of the Thomas predicted uptake capacity $\left(q_{T h}\right)$. These results are attributed to faster saturation of the column at higher initial nitrate concentrations and flow rates. In addition, the calculated values of $\mathrm{T}$ were slightly greater than the experimental counterparts at $50 \%$ breakthrough due to the model's relative simplicity. The estimated t derived from the Yoon-Nelson model hence may represent the upper boundary of the sorbent $50 \%$ breakthrough.

According to the literature data [19], the Thomas model is generally suitable for predicting the sorption process in the absence of limitations on external and internal diffusion. However, our previous research demonstrated that the overall sorption behavior of the pumpkin shell is mainly governed by external mass transfer and the intraparticle diffusion rate [26]. Thus, it can be concluded that the dynamic nitrate sorption onto the cationic modified pumpkin shell can be more accurately predicted via the Yoon-Nelson model than by the Thomas model in a continuous fixed bed column.

\section{Conclusion}

This study demonstrated that the cationic modified biomass of inedible pumpkin shell could be used as an effective biosorbent for the treatment of aqueous solution containing nitrate ions. Continuous experiments revealed the importance of the flow rate and the inlet solute concentration on nitrate sorption. Increasing the inlet solute concentration resulted in better column performance, while the lowest flow rate favored sorption. Thus, the breakthrough time and exhaustion time of the column bed decreased by increasing the flow rate and the influent concentration, whereas the uptake capacity increased by increasing the influent nitrate concentration. The optimal dynamic sorption capacity was found to be $30.97 \mathrm{mg} \mathrm{g}^{-1}$ and the total removal was $86 \%$ at the bed height of $13 \mathrm{~cm}$, the initial phosphate concentration of $100 \mathrm{mg} \mathrm{dm}^{-3}$, and the flow rate of $20 \mathrm{~cm}^{3} \mathrm{~min}^{-1}$. Column data obtained at different conditions were described using Thomas and Yoon-Nelson models. Both kinetic models were able to predict breakthrough curves. In particular, the breakthrough curve prediction by the Yoon-Nelson model was found to be satisfactory.

\section{Acknowledgement}

This work was supported by the Ministry of Education, Science, and Technological Development, the Republic of Serbia, through the Program funding scientific research (No. 451-03-68/2020-14/200133).

\section{References}

[1] U. Wiesmann, I.S. Choi, E.-M. Dombrowski, Fundamentals of biological wastewater treatment, Wiley- $\mathrm{VCH}$ Verlag GmbH\&Co, KGaA, Weinheim, Germany, 2006. 
[2] L. Fewtrell, Drinking-water nitrate, methemoglobinemia, and global burden of disease: a discussion, Environmental Health Perspectives, 112(14) (2004) 1371 - 1374.

[3] A. El Midaoui, F. Elhannouni, M.A. Menkouchi Sahli, L. Chay, H. Elabbassi, M. Hafsi, D. Largeteau, Pollution of nitrate in Moroccan ground water: removal by electrodialysis, Desalination, 136(1-3) (2001) 325 - 332.

[4] K. Hayrynen, J. Langwaldt, E. Pongracz, V. Vaisanen, M. Manttari, R.L. Keiski, Separation of nutrients from mine water by reverse osmosis for subsequent biological treatment, Minerals Engineering, 21(1) (2008) 2 - 9.

[5] Y. Cengeloglu, A. Tor, M. Ersoz, G. Arslan, Removal of nitrate from aqueous solution by using red mud, Separation and Purification Technology, 51 (2006) 374 . 378.

[6] P.C. Mishra, R.K. Patel, Use of agricultural waste for the removal of nitrate-nitrogen from aqueous medium, Journal of Environmental Management, 90 (2009) 519 - 522.

[7] S. Ebrahimi, D.J. Roberts, Sustainable nitratecontaminated water treatment using multi cycle ionexchange / bioregeneration of nitrate selective resin, Journal of Hazardous Materials, 262 (2013) 539 - 544.

[8] C. Su, R.W. Puls, Nitrate reduction by zerovalent iron. Effects of formate, oxalate, citrate, chloride, sulfate, borate, and phosphate, Environmental Science and Technology, 38(9) (2004) 2715 - 2720.

[9] D. Bojić, M. Momčilović, D. Milenković, J. Mitrović, P. Bankovic, N. Velinov, G. S. Nikolić, Characterisation of a low cost Lagenaria vulgaris based carbon for ranitidine removal from aqueous solutions, Arabian Journal of Chemistry, 10(7) (2017) 956 - 964.

[10] D. Marković Nikolić, A. Bojić, D. Bojić, D. Cvetković, M. Cakić, G. S. Nikolić, Preconcentration and immobilization of phosphate from aqueous solutions in environmental ceanup by a new bio-based anion exchanger, Waste and Biomass Valorization, 11(4) (2020) 1373 - 1384.

[11] D. Marković Nikolić, A. Bojić, D. Bojić, M. Cakić, D. Cvetković, G.S. Nikolić, The biosorption potential of modified bottle gourd shell for phosphate: equilibrium, kinetic and thermodynamic studies, Chemical Industry and Chemical Engineering Quarterly, 24(4) (2018) 319 . 332.

[12] D. Marković Nikolić, M. Cakić, G. Petković, G.S. Nikolić, Kinetics, thermodynamics and mechanisms of phosphate sorption onto bottle gourd biomass modified by (3-chloro2-hydroxypropyl) trimethylammonium chloride, Progress in Reaction Kinetics and Mechanism, 44(3) (2019) 267285.

[13] M. Kostić, A.P. Hurt, D. Milenković, N. Velinov, M. Petrović, D. Bojić, D. Marković Nikolić, A. Bojić, Effects of ultrasound on removal of ranitidine hydrochloride from water by activated carbon based on Lagenaria siceraria, Environmental Engineering Science, 36(2) (2019) 237 . 248.

[14] G.S. Nikolić, D. Marković Nikolić, M. Kostić, M. Durmišević, M. Cakić, Development and characterisation of miscellaneous cationic sorbents based on lignocellulosic gourd shell, Advanced Technologies, 8(2) (2019) 46 - 57.

[15] D. Marković Nikolić, G.S. Nikolić, Nitrate sorption by modified Lagenaria vulgaris biomass: kinetic and equilibrium studies, Journal Materials Protection (Zaštita Materijala), 58(4) (2017) 530 - 540.

[16] A. Keranen, T. Leiviska, O. Hormi, J. Tansknen, Removal of nitrate by modified pine sawdust: effects of temperature and co-existing anions, Journal of Environmental Management, 147 (2015) 46 - 54.

[17] F.W. Sousa, A.G. Oliveira, J.P. Ribeiro, M.F. Rosa, D. Keukeleire, R.F. Nascimento, Green coconut shells applied as adsorbent for removal of toxic metal ions using fixed-bed column technology, Journal of Environmental Management, 91 (2010) 1634 - 1640.

[18] U.S. Orlando, A.U. Baes, W. Nishijima, M. Okada, Preparation of agricultural residue anion exchangers and its nitrate maximum sorption capacity, Chemosphere, 48 (2002) 1041 - 1046.

[19] H. Patel, Fixed-bed column adsorption study: a comprehensive review, Applied Water Science, 9(45) (2019) 1 - 17.

[20] M. Shafeeyan, W. Daud, A. Shamiri, A review of mathematical modeling of fixed-bed columns for carbon dioxide adsorption, Chemical Engineering Research and Design, 92(5) (2014) 961 - 988.

[21] V.K. Gupta, I. Ali, Environmental water: advances in treatment, remediation and recycling, Chapter 2 Water treatment for inorganic pollutants by adsorption technology, Elsevier Ins, 2012, p. 29 - 33.

[22] F. Kafshgari, A.R. Keshtkar, M.A. Mousavian, Study of $\mathrm{Mo}(\mathrm{VI})$ removal from aqueous solution: application of different mathematical models to continuous biosorption data, Iranian Journal of Environmental Health Science and Engineering, 10(1) (2013) 1 - 11

[23] H.C. Thomas, Heterogeneous ion exchange in a flowing system, Journal of the American Chemical Society, 66 (1944) 1664 - 1466.

[24] Y.H. Yoon, J.H. Nelson, Breakthrough time and adsorption capacity of respirator cartridges, American Industrial Hygiene Association Journal, 53 (1992) 303 - 316.

[25] W. Zhang, L. Dong, H. Yan, H. Li, Z. Jiang, X. Kan, H. Yang, A. Li, R. Cheng, Removal of methylene blue from aqueous solutions by straw based adsorbent in a fixedbed column, Chemical Engineering Journal, 173(2) (2011) $429-436$.

[26] D. Marković, Sinteza katjonskih ligno-celuloznih sorbenata i primena za uklanjanje anjonskih polutanata iz vode, Doktorska disertacija, PMF - Departman za hemiju Niš, 2018.

[27] APHA, Standard methods for the examination of water and wastewater, 20th edition, M.A.H. Franson ed., American Public Health Association, Washington, 2000.

[28] D. Helard, S. Indah, D.P. Kiflia, Removal of nitrate from groundwater by column using pumice as adsorbent as an effort for water resources conservation, International Conference on Applied Sciences, Information and Technology, IOP Publishing, Series: Materials Science and Engineering, 846 (2020) 012059, doi:10.1088/1757899X/846/1/012059.

[29] E. Worch, Adsorption technology in water treatment: fundamentals, processes, and modeling, De Gruyter, 2012, p. 169-196.

[30] WHO, Nitrate and nitrite in drinking-water, In: "World Health Organization Guidelines for drinking water quality", G.J.A. Speijers ed., WHO Press, Geneva, 2011.

[31] X. Xing, B.-Y. Gao, Q.-Q. Zhong, Q.-Y. Yue, Q. Li, Sorption of nitrate onto amine-crosslinked wheat straw: characteristics, column sorption and desorption properties. Journal of Hazardous Materials, 186 (2011) 206 - 211.

[32] R. Han, Y. Wang, X. Zhao, Y. Wang, F. Xie, J. Cheng, M. Tang, Adsorption of methylene blue by phoenix tree leaf 
powder in a fixed-bed column: experiments and prediction of breakthrough curves, Desalination, 245 (2009) 284 297.

Izvod

\section{STUDIJA SORPCIJE NA KOLONI SA FIKSNIM SLOJEM ZA UKLANJANJE NITRATA KATJONSKI MODIFIKOVANOM KOROM NEJESTIVE BUNDEVE}

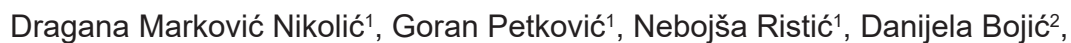
Miloš Durmišević ${ }^{3}$, Stanko Žerajić ${ }^{3}$, Goran S. Nikolić ${ }^{3}$

\footnotetext{
${ }^{1}$ Akademija strukovnih studija Južna Srbija, Odsek za tehnološko umetničke studije, Leskovac, Srbija

2 Univerzitet u Nišu, Prirodno-matematički fakultet, Departman za Hemiju, Niš, Srbija

3 Univerzitet u Nišu, Tehnološki fakultet, Leskovac, Srbija
}

Kolona sa fiksnim slojem katjonski modifikovane kore nejestive bundeve kao sorbenta primenjena je za uklanjanje nitratnih anjona iz vodenog rastvora. Performanse kolone sa fiksnim slojem procenjene su variranjem ulazne koncentracije nitrata (50 $\mathrm{mg} \mathrm{dm}^{-3}$ i $\left.100 \mathrm{mg} \mathrm{dm}^{-3}\right)$ i brzine protoka $\left(20 \mathrm{~cm}^{3} \mathrm{~min}^{-1}\right.$ i $\left.40 \mathrm{~cm}^{3} \mathrm{~min}^{-1}\right)$, pri visini sloja sorbenta od $13 \mathrm{~cm}$. Dobijeni eksperimentalni rezultati su pokazali da povećanje koncentracije polaznog rastvora nitrata utiče na povećanje količine nitrata u efluentu i smanjuje vreme proboja. Veća brzina protoka dovodi do bržeg iscrpljivanja kolone, što može rezultirati skraćenim životnim vekom kolone. U ovoj studiji, efikasno uklanjanje nitrata od $86 \%$ ostvareno je pri brzini protoka od $20 \mathrm{~cm}^{3} \mathrm{~min}^{-1}$ sa polaznim rastvorom nitrata od $100 \mathrm{mg} \mathrm{dm}^{-3}$. Odnos između sorpcionog kapaciteta ovog sorbenta i različitih parametara kolone procenjen je i predviđen pomoću dva različita kinetička modela teorijske krive proboja: Tomasov i Jun-Nelsonov model. Ova studija je potvrdila da katjonski modifikovana kora tikve u koloni sa fiksnim slojem ima dobar potencijal za uklanjanje nitratnih anjona iz vodenih rastvora.
(ORIGINALNI NAUČNI RAD) UDK 66.081:635.62 DOI: $10.5937 /$ savteh2002005M

Ključne reči: kora bundeve, sorpcija nitrata, kolona sa fiksnim slojem, krive proboja, modelovanje 